\title{
Pengaruh Waktu Pemberian Gonadotropin Releasing Hormone (GnRH) terhadap Jumlah Korpus Luteum dan Kecepatan Timbulnya Berahi pada Sapi Pesisir
}

\section{Timely Effect of Injecting GnRH (Gonadotropin Releasing Hormone) on Number of Corpus Luteum Production from the Pesisir Cows}

\author{
T.Afriani, Jaswandi, Defrinaldi, Y.E.Satria \\ Fakultas Peternakan Universitas Andalas Padang \\ E-Mail : tinda_a@yahoo.co.id \\ (Diterima : 3 Februari 2014, Disetujui : 13 April 2014)
}

\begin{abstract}
ABSTRAK
Penelitian ini dilakukan untuk mengetahui kecepatan timbulnya berahi dari dosis Gonadotropin Releasing Hormone (GnRH) yang berbeda dan pengaruh waktu pemberian $\mathrm{GnRH}$ terhadap jumlah korpus luteum pada sapi Pesisir. Materi yang digunakan yaitu 12 ekor induk sapi Pesisir, hormon $\mathrm{PGF}_{2 \alpha}$ dan GnRH. Terdiri dari dua tahap, pertama Induk sapi disinkronisasi dengan

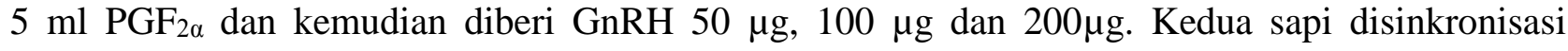
dengan $5 \mathrm{ml} \mathrm{PGF}_{2 \alpha}$ dan kemudian diberi $\mathrm{GnRH}$ dosis hasil penelitian tahap pertama dan dibagi atas 4 waktu penyuntikan, yaitu $\mathrm{A}(16), \mathrm{B}(32), \mathrm{C}(48)$, dan $\mathrm{D}(64)$ jam. Peubah yang diamati adalah waktu terjadinya estrus setelah diberi dosis yang berbeda dan jumlah korpus luteum (CL) yang terbentuk dari waktu penyuntikan yang berbeda. Pengolahan data dilakukan dengan menggunakan Rancangan Acak Lengkap (RAL). Hasil penelitian menunjukkan bahwa dosis GnRH yang tercepat menunjukan gejala estrus adalah $100 \mu \mathrm{g}$ dengan rataan $45.42 \pm 2.24 \mathrm{jam}, 200 \mu \mathrm{g}$ rataan $51.33 \pm 4.51$ jam dan $50 \mu \mathrm{g}$ rataan $76.53 \pm 11.92$ jam. Waktu pemberian GnRH berpengaruh terhadap jumlah CL yang terlihat dari jumlah CL dari masing-masing perlakuan. Perlakuan $\mathrm{C}(48)$ jam menunjukkan jumlah CL yang paling banyak dengan rataan $4.33 \pm 1.15$ dan diikutiB(32) jam dengan rataan $3.67 \pm 1.53$, perlakuan $\mathrm{A}(16)$ jam dengan rataan1.67 \pm 1.15 perlakuan $\mathrm{D}(64)$ dengan rataan $1.67 \pm 0.58$.
\end{abstract}

Kata kunci : Sapi Pesisir, PGF2 $\alpha$, GnRH, Korpus Luteum.

\begin{abstract}
The study was conducted to determine the timely effect of injecting GnRH (gonadotropin releasing hormone) on number of corpus luteum production from the Pesisir cows. The study materials consisted of 12 heads Pesisir cow, $P G F_{2 \alpha}$ and GnRH hormone (gonadorelin). The study consists of two stages, the first the cattle were synchronized with $5 \mathrm{ml} P G F_{2 \alpha}$ and then were gave

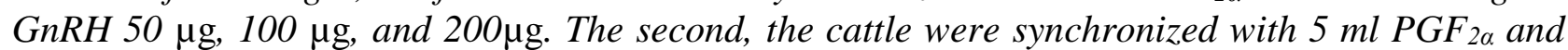
then were gave doses of GnRH first phase of the research results and divided into four time injection, that were $A(16), B(32), C(48)$, and $D(64)$ hours. The parameters were measured the time of estrus after been gave a different doses and the number of corpus luteum (CL) formed from different time injection. Experiment used a completely randomized design (CRD). The results showed that doses of GnRH fastest showing sign of estrus was $100 \mu \mathrm{g}$ with average $45.42 \pm 2.24$ hours, $200 \mu \mathrm{g}$ with average $51.33 \pm 4.51$ hoursand $50 \mu \mathrm{g}$ with averaging $76.53 \pm 11.92$ hours. GnRH Time effect on the $C L$ number seen from the $C L$ treatment. Treatment $C(48)$ hours indicated the $C L$ number most widely by average $4.33 \pm 1.15$ and followed by $B(32)$ hours with the average $3.67 \pm 1.53$, treatment $A(16)$ hours with the average $1.67 \pm 1.15$ treatment $D(64)$ with the average of $1.67 \pm 0.58$.
\end{abstract}

Keywords :Pesisir Cattle, PGF 2, GnRH, Corpus Luteum. 


\section{PENDAHULUAN}

Untuk memenuhi kebutuhan masyarakat terhadap daging sapi pemerintah Indonesia telah mencanangkan swasembada daging sapi nasional.Program ini pada awalnya diharapkan tercapai pada tahun 2010 kemudian direvisi menjadi menjadi tahun 2014.Untuk mendukung program tersebut salah satu potensi yang terdapat di Sumatera Barat adalah ternak lokal sapi Pesisir. Keunggulan sapi ini terutama tahan terhadap cekaman lingkungan yang ekstrim seperti panas, dan dapat memanfaatkan bahan pakan berkualitas rendah, selain itu tidak memerlukan pemeliharaan khusus, seperti pada sapi lainnya.Kendala utama dalam pengembangan sapi ini adalah masih rendahnya laju peningkatan populasi.

Hal ini terutama disebabkan kekurangan dan ketidak seimbangan hormonal sehingga terjadi anestrus atau berahi tenang dan estrus tidak disertai ovulasi setelah postpartum (Peter et al.,2009). Belakangan ini upaya manipulasi hormonal untuk mendorong estrus dilakukan menggunakan GnRH (Hardjopranyoto, 1995).

Secara alamiah hormon ini dihasilkan oleh kelenjer hipotalamus untuk menstimulasi kelenjer hipofysa menghasilkan hormon follicle stimulating hormone (FSH) dan luteinizing hormone (LH). Hormon GnRH pada dasarnya berfungsi untuk merangsang FSH bekerja sama dengan LH menstimulir pematangan folikel dan pelepasan estrogen (Toelihere, 1985). Walker et al., (2005) melaporkan keuntungan penyuntikan dua kali hormon GnRH terhadap jumlah pembentukan folikel pada sapi akan tinggi dan akan berkorelasi dengan peningkatan kadar hormon estrogen yang mempengaruhi estrus dan pembentukan CL setelah penyuntikan $\mathrm{PGF}_{2 \alpha}$.

Dalam penelitian tersebut juga dikemukakan bahwa sapi yang mendapat $\mathrm{GnRH}$ pada waktu 48 dan 72 jam setelah penyuntikan $\mathrm{PGF}_{2 \alpha}$ menghasilkan jumlah folikel yang lebih tinggi dibandingkan sapi yang tidak mendapat perlakuan GnRH.
Pemanyun (2009) telah melakukan penelitian dengan pemberian GnRH dosis 250 $\mu \mathrm{g} / \mathrm{im} 24$ jam setelah sinkronisai $\mathrm{PGF}_{2 \alpha}$, menunjukkan bahwa sapi akan memperlihatkan gejala estrus pada hari ke 7 . Hal ini menunjukkan bahwa perkembangan folikel akan bervariasi setelah penyuntikan $\mathrm{PGF}_{2 \alpha}$, sehingga akan berdampak pada pembentukan jumlah CL dan kecepatan timbulnya birahi (Salisbury dan VanDemark, 1985).

Penelitian dibagi menjadi dua tahap : tahap pertama bertujuan untuk mengetahui kecepatan timbulnya berahi dari dosis $\mathrm{GnRH}$ yang berbeda, tahap kedua mengetahui pengaruh pemberian hormon GnRH pada waktu yang berbeda terhadap jumlah korpus luteum pada sapi.

\section{METODE}

Materi yang digunakan adalah induk Sapi Pesisir sebanyak 12 ekor dengan umur sekitar 3-4 tahun.Pakan yang diberikan adalah hijauan dan kosentrat berupa dedak dan mineral.Bahan yang digunakan antara lain adalah Prostaglandin F-2 alpha ( $\left.\mathrm{PGF}_{2 \alpha}\right)$, $\mathrm{GnRH}$ gonadorelin (Fertagyl $^{\mathrm{TM}}$, Intervet), alkohol $70 \%$.

Metode Penelitian tahap 1 adalah semua sapi diserentakkan birahinya dengan penyuntikan $5 \mathrm{ml} \mathrm{PGF}_{2 \alpha}$, setelah 48 jam dilakukan penyuntikan GnRH dengan dosis 50 $\mu \mathrm{g}, 100 \mu \mathrm{g}$ dan $200 \mu \mathrm{g}$ intra muscular. Diamati setiap hari setelah penyuntikan, terlihat estrus, sampai estrus tidak terlihat lagi (jam).

Tahap 2, setelah didapati waktu tercepat dari ketiga dosis dilakukan penelitian lanjutan dengan penyuntikan $5 \mathrm{ml} \mathrm{PGF}_{2 \alpha}$, setelah 48 jam dilakukan penyuntikan $\mathrm{GnRH}$ dosis tercepat hasil penelitian tahap pertama dengan dibagi 4 perbedaan waktu penyuntikan, 16, 32, 48, dan 64 (jam).

Data hasil penelitian kecepatan timbulnya birahi dan jumlah korpus luteum Dianalisis dengan Analisis of Variansi (Anova) menurut Rancangan Acak Lengkap (Steel and Torrie, 1995). 
HASIL DAN PEMBAHASAN

Pengaruh Pemberian Dosis GnRH yang Berbeda terhadap Kecepatan Timbulnya Birahi

Hasil penelitian menunjukkan Kecepatan timbulnya berahi Sapi Pesisir setelah di injeksi dengan $\mathrm{PGF}_{2 \alpha}$ dengan tiga dosis GnRH yang berbeda berkisar antara 34120.25 jam. Rataan kecepatan timbulnya birahi Sapi Pesisir pada masing-masing perlakuan dapat dilihat pada Tabel 1.Hasil analisa statistik menunjukkan bahwa dosis hormon GnRH berpengaruh sangat nyata $(\mathrm{P}<0.01)$ terhadap kecepatan timbulnya birahi. Hasil uji DMRT menunjukkan pemberian GnRH sebanyak $50 \mathrm{ug} / \mathrm{ml}$ menghasilkan kecepatan birahi sangat nyata $(\mathrm{P}<0.01)$ lebih lambat dari pemberian GnRH dengan dosis $100 \mu \mathrm{g} / \mathrm{ml}$ dan $200 \mu \mathrm{g} / \mathrm{ml}$. Rata-rata $76.53 \pm$ 11.92 jam untuk dosis $50 \mathrm{ug} / \mathrm{ml}$ dan hasil analisis statistik pada dosis $100 \mu \mathrm{g} / \mathrm{ml}$ dan 200 $\mu \mathrm{g} / \mathrm{ml}$ GnRH menunjukkan hasil berbeda tidak nyata $(\mathrm{P}>0.05)$ antar perlakuan. Ini disebabkan oleh perbedaan pertumbuhan folikel pada ovarium, semakin tinggi kadar GnRH maka akan menstimulasi hipofisa untuk menghasilkan hormon FSH dan LH.

Sesuai dengan pendapat Hafez (2000) bahwa GnRH berfungsi untuk menginduksi pelepasan FSH dan LH di hipofisa anterior sehingga menyebabkan perkembangan folikel dan terjadinya berahi. Perkembangan folikel menyebabkan tingginya kadar hormon estogen yang menginduksi gejala berahi pada sapi. Sesuai dengan penelitian Putro, (2008) bahwatehnik sinkronisasi dapat diaplikasikan dengan pemberian $250 \mu \mathrm{g} / \mathrm{ml} \mathrm{GnRH}$ untuk sapi betina dengan berat badan sekitar 400 kilogram. Artinya, sapi yang lebih besar atau lebih kecil dari berat tersebut pemberian $\mathrm{GnRH}$ dikonversikan sesuai dengan taksiran beratbadannya.
Hal lain yang menyebabkan adanya variasi antar individu ternak kemungkinan disebabkan oleh adanya peningkatan estradiol yang berbeda dari masing-masing ternak (Sudjana, 1992).

Sesuai dengan penyataan Motlomelo et al., (2002) bahwa berbedanya waktu timbulnya estrus disebabkan karena tidak terjadinya peningkatan estradiol pada ternak selama beberapa hari setelah progesteron mencapai tingkat basal.

Berdasarkan hasil pengamatan selama penelitian didapatkan kecepatan munculnya berahi sapi Pesisir antar perlakuan berkisar antara $57.76 \pm 16.53$ jam dan yang tercepat menunjukan gejala berahi adalah dosis 100 $\mu \mathrm{g} / \mathrm{ml}$ dengan rataan $45.42 \pm 2.24$.

\section{Pengaruh Pemberian Hormon GnRH Pada Waktu Yang berbeda Terhadap Jumlah Korpus Luteum Pada Sapi.}

Hasil penelitian menunjukkanpengaruh waktu pemberian $\mathrm{GnRH}$ terhadap jumlah CL pada sapi Pesisir dapat disajikan pada Tabel 2.Dari Tabel 2 terlihat bahwa jumlah CL dari masing-masing induk sapi penelitian berkisar antara 1-5 buah. Jumlah CL yang tertinggi terdapat pada perlakuan $C(48)$ jamdengan rataan $4.33 \pm 1.15$, perlakuan $\mathrm{B}(32)$ jam dengan rataan $3.67 \pm 1.53$ dan pada perlakuan $\mathrm{A}(16)$ jam dengan rataan $1.67 \pm 1.15, \mathrm{D}(64)$ jam dengan rataan $1.67 \pm 0.58$ memiliki jumlah $\mathrm{CL}$ yang lebih sedikit dibandingkan dengan jumlah CL pada perlakukan C dan B. Hasil analisis statistik menunjukkan bahwa waktu pemberian hormon $\mathrm{GnRH}$ berpengaruh sangat nyata $(\mathrm{P}<0.01)$ terhadap jumlah korpus luteum.

Hasil uji lanjut dengan DMRT menunjukkan perlakuan $\mathrm{C}$ berbeda nyata dengan perlakuan $\mathrm{B}(\mathrm{P}<0.05)$, sedangkan perlakuan A dan $\mathrm{D}$ perbedaan yang sangat nyata $(\mathrm{P}<0.01)$.

Tabel 1. Rataan kecepatan munculnya birahi sapi Pesisir selama penelitian (jam).

\begin{tabular}{cc}
\hline Perlakuan Dosis GnRH & Kecepatan Timbulnya Birahi (Jam) \\
\hline $50 \mu \mathrm{g} / \mathrm{ml} \mathrm{GnRH}$ & $76.53 \pm 11.92^{\mathrm{a}}$ \\
$100 \mu \mathrm{g} / \mathrm{ml} \mathrm{GnRH}$ & $45.42 \pm 2.24^{\mathrm{b}}$ \\
$200 \mu \mathrm{g} / \mathrm{ml} \mathrm{GnRH}$ & $51.33 \pm 4.51^{\mathrm{b}}$ \\
\hline
\end{tabular}


Tabel 2. Jumlah total korpus luteum setelah penyuntikan GnRH

\begin{tabular}{ccccc}
\hline \multirow{2}{*}{ Ulangan } & \multicolumn{4}{c}{ Perlakuan } \\
\cline { 2 - 5 } & $\mathrm{A}(16$ jam $)$ & $\mathrm{B}(32$ jam $)$ & $\mathrm{C}(48$ jam $)$ & $\mathrm{D}(64$ jam $)$ \\
\hline I & 1 & 3 & 3 & 2 \\
II & 2 & 4 & 5 & 1 \\
III & 2 & 4 & 5 & 5 \\
\hline Total & 5 & 11 & 13 & $1.67 \pm 0.58^{\mathrm{a}}$ \\
\hline Rataan & $1.67 \pm 1.15^{\mathrm{a}}$ & $3.67 \pm 1.53^{\mathrm{b}}$ & $4.33 \pm 1.15^{\mathrm{c}}$ &
\end{tabular}

Keterangan : Huruf yang berbeda pada baris yang sama menunjukkan berbeda sangat nyata $(\mathrm{P}<0.01)$.

Hal ini menunjukan induksi GnRH 48 jam menyebabkan semakin banyak ovulasi terjadi sebagai respon terhadap pelepasan hormon FSH dan LH oleh hypofisa akibat stimulasi GnRH yang disuntikan. Sesuai pendapat Toelihere, (1985) bahwa hormon GnRH pada dasarnya berfungsi untuk merangsang induksi LH atau FSH yang bekerja sama menstimulir folikel dan selanjutnya pembentukan CL. Jumlah CL dalam penelitian ini tidak jauh berbeda jika dibandingkan dengan penelitian Suardi (2008) yang melaporkan jumlah CL sapi potong yang di superovulasi yaitu $4.38 \pm 7.30$.

Yusuf (1990) menyatakan bahwa banyaknya $C L$ yang berkembang di dalam ovarium sesudah penyuntikan hormon FSH memberikan gambaran tentang keberhasilan superovulasi dari ternak.Semakin banyak CL yang terbentuk pada ovarium makin tinggi tingkat keberhasilan superovulasi.Hal ini dapat dipahami karena keberhasilan CL identik dengan respon superovulasi dan ovulasi yang terjadi.

Jumlah CL yang lebih banyak terbentuk pada pemberian GnRH 48 jam setelah penyuntikan PGF2 $\alpha$ berkaitan dengan peranan hormon FSH dan LH dan fase siklus estrus setelah pemberian PGF2 $\alpha$. Penyuntikan PGF2 $\alpha$ menyebabkan terjadinya regresi CL (fase diestrus) sehingga hormon akan masuk fase proestrus. Menurut Frandson (1996).pada fase proestrus terjadi perkembangan folikel dan perkembangan folikel tersebut dibawah stimulasi hormon FSH.

$\mathrm{PGF}_{2 \alpha}$ tidak langsung merangsang organ sasaran yaitu CL. Sesuai dengan pendapat bahwa $\mathrm{PGF}_{2 \alpha}$ yang disuntikkan akan memasuki aliran darah menuju ovarium (Menchaca dan Rubianes, 2001). Akibat aksi dari $\mathrm{PGF}_{2 \alpha}$ tersebut akan terjadi vasokonstriksi, sehingga aliran darah menuju ovarium mengakibatkan suplai makanan yang dibutuhkan ovarium akan berkurang bahkan terhenti. Sehingga CL yang fungsional meluluh atau regresi.Hancurnya CL tersebut menyebabkan terhentinya sekresi hormon progesteron, diikuti dengan naiknya FSH untuk merangsang pertumbuhan folikel dan terjadinya estrus.

Hasil yang lebih rendah pada perlakuan A (pemberian GnRH 16 jam) diduga ternak sapi baru akan memasuki fase proestrus, sebaliknya pada perlakuan D (pemberian GnRH 64 jam setelah $\mathrm{PGF}_{2 \alpha}$ ) ternak telah melewati fase proestrus sehingga rekruitmen folikel yang akan berkembang telah selesai, dan hormon masuk fase estrus. Menurut Frandson (1996) pada fase estrus hormon yang lebih banyak berperan adalah hormon LH. Jadi pemberian GnRH yang terlalu cepat dapat mengakibatkan terbuang percuma karena proses lisisnya CL oleh PGF2 $\alpha$ belum sempurna, yang mengakibatkan hormon progesteron masih tinggi sehingga menyebabkan positif feedback belum bisa berlangsung, sehingga FSH dan LH belum dapat dikeluarkan dan poses estrus belum bias berlangsung De Castro et al., (1999).

\section{KESIMPULAN}

Waktu pemberian GnRH berpengaruh terhadap kecepatan berahi.Waktu yang tercepat dari tiga dosis $\mathrm{GnRH}$ yang berbeda adalah $100 \mu \mathrm{g} / \mathrm{ml}$ dengan rataan $45.42 \pm 2.24$. Waktu penyuntikan hormon GnRH berpengaruh terhadap jumlah CL. CL yang ter- 
banyak hasilkan pada penyuntikan hormone GnRH 48 jam dengan rataan $4.33 \pm 1.15$, lalu pada waktu penyuntikan 32 jam sebanyak $3.67 \pm 1.53,16$ jam sebanyak $1.67 \pm 1.15$, dan 64 jam sebanyak $1.67 \pm 0.58$.

\section{DAFTAR PUSTAKA}

De Castro T, Rubianes E, Menchaca A, Rivero A. 1999. Ovarian dynamics, serum estradiol and progesterone concentrations during the interovulatory interval in goats. Theriogenology. 52:399-411.

Frandson, R. D. 1996. Anatomi dan Fisiologi Ternak. Edisi ke-7. Gajah Mada University Press, Yogyakarta.

Hardjopranyoto, H. S. 1995. Ilmu Kemajiran Pada Ternak. Airlangga University Press, Surabaya.

Hafez B. 2000. Reproduction in Farm Animals.Lippincot Williams \& Wilkins. Philadelphia. Pp. 59-63.

Menchaca A dan Rubianes E. 2001.Effect of high progesterone concentrations during the early luteal phase on the length of the ovulatory cycle of goats.Anim. Reprod. Sci. 68:69-76.

Motlomelo K.C., Greyling J.P.C., Schwalbach L.M.J. (2002): Synchronisation of oestrus in goats: the use of different progestagen treatments. Small Ruminant Research. 45:45-49.

Pemanyun, T. G. O. 2009. Induksi estrus dengan PMSG dan GnRH pada sapi perah anestrus postpartum. Buletin Veteriner Udayana. Vol 2 No 1.

Peter AT, Levine H, Drost M, bergfelt DR. 2009. Compilation of classical and contemporary terminology used to describe morphological aspects of ovarian dynamics in cattle. Theriogenology. 71:1343-1357.

Putro, P. P. 2008. Dinamika perkembangan folikel dominan dan korpus luteum setelah sinkronisasi estrus pada Sapi Peranakan Friesian Holstein. Disertasi S3, Sekolah Pascasarjana Universitas Gadjah Mada, Yogyakarta.

Salisbury, G. W. dan N. L. VanDemark. 1985. Fisiologi Reproduksi dan Inseminasi Buatan pada Sapi. Gajah Mada University Press, Yogyakarta.

Steel, R. G. D dan J. H. Torrie. 1991. Prinsip dan Prosedur Statistik Suatu Pendekatan Biometrik. Edisi kedua.Cetakan kedua. Alih Bahasa B. Sumantri. PT. Gramedia Pustaka Utama, Jakarta.

Suardi. 2008. Jumlah dan kualitas embrio hasil super ovulasi pada sapi perah non laktasi dan sapi potong. Skripsi. Fakultas Peternakan Universitas Andalas, Padang.

Sudjana. 1992. Metode Statistika. Bandung : Tarsito.

Toelihere, M. R. 1985. Fisiologi Reproduksi pada Ternak. Angkasa Bandung, Bandung.

Walker, R. S., P. D. Burns, J. C. Whittier, G. E. Seidel, and D. D. Zalesky. 2005. Evaluation of gonadotropin releasing hormone and insemination time using the CO-synch protocol in beef cows. Prof. Anim. Sci. 21:190.

Yusuf. T. L. 1990. Pengaruh prostaglandin F2 alpha dan gonadotropin terhadap aktivitas estrus dan superovulasi dalam rangkaian kegiatan transfer embrio pada sapi Fries Holland, Bali dan Peranakan Ongole. Disertasi.Fakultas Pascasarjana Institut Pertanian Bogor (IPB). 